\title{
THE KNOBE EFFECT FROM THE PERSPECTIVE OF THOMISTIC ETHICS: THE PROBLEM OF NORMATIVE ORDERS AND COMPETENCES*
}

\begin{abstract}
This article discusses how to interpret the so-called Knobe effect, which refers to the asymmetry in judgments about the intentionality of the side effects caused by one's actions. The observed tendency is explained through the "moral undertone" of the actions judged. So far, discussions have mostly been held among philosophers in the analytical tradition that is, those who see the theory of morality largely as an ethics of rules. The analysis developed in this article advances the research carried out so far to include teleological ethics, most notably the tradition of Thomistic ethics. Philosophical discussions address the problem of normative orders, focusing in particular on two types of cognition concerned, respectively, with moral judgments and facts. Investigating this issue proves to be helpful not only to explain the Knobe effect, but also to better understand the very notion of an intentional action as employed in the philosophy of action. As a result of this analysis, the Author explains the existing asymmetry in the attribution of intentionality to actions with the respondents' confusion between cognitive orders. This problem brings us to the issue of normative competences. In analyzing the Knobe effect, normative competences could be responsible for the classification of the data collected and separation of the "purely informative" order from the order of moral judgments, referring to norms or values.
\end{abstract}

Keywords: Knobe effect; side effect; intentional actions; normativity; competences; Thomistic ethics

1. Introduction: Research context and purpose of the article. 2. The Knobe effect and its explanation. 3. Morality and cognition. 4. The scope of morality. 5. Moral responsibility from a Thomistic perspective. 6 . The problem of normative orders and competences. 7. Conclusions.

* This article was originally published in Polish as: A. Waleszczyński, Efekt Knobe'a z perspektywy etyki tomistycznej. Problem porządków i kompetencji normatywnych, Studia Philosophiae Christianae 54(2018)1, 65-92. The translation of the article into English was financed by the Ministry of Science and Higher Education of the Republic of Poland as part of the activities promoting science - Decision No. 676/P-DUN/2019 of 2 April 2019. Translation made by GROY Translations 


\section{INTRODUCTION: RESEARCH CONTEXT AND THE PURPOSE OF THE ARTICLE}

Joshua Knobe presented the results of his experiment in an article entitled Intentional Action and Side Effects in Ordinary Language, which is very well known in the world of experimental philosophy ${ }^{1}$. These results intrigued many philosophers and psychologists and revealed a new problem which had not been clearly resolved so far. The perception of an intentional action was examined, namely, whether a side effect of an action would be assessed as intentional. The collected results showed an interesting asymmetry in attributing the intentionality of inducing a side effect. It is also interesting from the ethical point of view, since the asymmetry of the results obtained by Knobe himself, as well as by some of the interpreters, is explained by the "moral connotation" of the assessed acts. As a result of this interpretation, Knobe formulated a hypothesis which Frank Hindriks ${ }^{2}$ called the Moral Valence Hypothesis ${ }^{3}$. It states that the moral value of side effects affects the attribution of intentionality. In this article, we will refer to this hypothesis as a moral hypothesis.

Until now, discussions have been conducted mainly among philosophers, who see the theory of morality primarily as the ethics of principles. Therefore, it would be intriguing to expand the reflection on morality with selected teleological ethics. This article will undertake analyses taking into account the tradition of Thomistic ethics. Attention will also be focused on the problem of normative orders and, consequently on two aspects of cognition: "informing about the moral evaluation" of an object and "informing about facts" (empirical facts) concerning human action. The examination of this issue may be helpful not only in the search for an explanation of the asymmetry in attributing the intentionality of action, but also in getting a better understanding of the issue of intentional action itself.

$1 \mathrm{~J}$. Knobe, Intentional Action and Side Effects in Ordinary Language, Analysis 63(2003)3, 190-194.

2 F. Hindriks, I. Douven, H. Singmann, A New Angle on the Knobe Effect: Intentionality Correlates with Blame, not with Praise, Mind and Language 31(2016)2, 204-220.

3 J. Knobe, The Concept of Intentional Action. A Case Study in the Uses of Folk Psychology, Philosophical Studies 130(2006)2, 203-231. 
The purpose of this article is to indicate the theoretical basis on which it is possible to demonstrate that in the quest to explain the Knobe effect, there is a confusion of normative, or in other words, cognitive orders. It is primarily a matter of distinguishing between the cognition of reality according to norms understood as patterns that inform human beings about the cause and effect order (the empirical order perceived in "purely informative" cognition), which refers to events, and the cognition of reality according to norms or values that give rise to moral judgment or classification, which are defined as actions. ${ }^{456}$ In other words, the problem of confusing the two orders can be reduced to the issue of normative competences, which, in the context of analyzing the Knobe effect, would be responsible for identifying the data collected and separating the "purely informative" order from the evaluator's order, referring to norms or values. This problem was addressed by J. Knobe in the article entitled Person as scientist, person as moralist ${ }^{7}$. He suggested that there are two ways to approach the problems presented. One would correspond to a colloquial perception of intentional action that would be morally tinged. The second would represent a "scientific" approach that would be cut off from the influence of ethical judgements. However, the problem seems to concern the cognitive abilities of people and the more fundamental competences that could be described as normative.

4 The issue of normativity, which goes beyond the legal and moral order, is developed by Michał Piekarski in his research: M. Piekarski, Od typiki doświadczenia do normatywnej antycypacji. Przyczynek do fenomenologii normatywności, Filo-Sofija 33(2016)2, 71-86; Idem, Efekt Knobe’a, normatywność i racje działania, Filozofia Nauki 97(2017)1, 109-128.

5 The understanding and distinction between of "event" and "action" comes from F. Ricken and is presented in a slightly different way than is usually assumed in the philosophy of action, cf. K. Paprzycka, Analityczna filozofia działania. Problemy i stanowiska, in: Przewodnik po filozofii umysłu, eds. M. Miłkowski, R. Poczobut, WAM, Kraków 2012, 465-494.

6 In this article, I will refer primarily to the Thomistic tradition and use the category of norm and the accompanying evaluation. However, it seems to me that similar conclusions can also be drawn from other traditions, such as phenomenological ethics.

7 J. Knobe, Person as scientist, person as moralist, Behavioral and Brain Sciences 33(2010)4, 315-329. 


\section{THE KNOBE EFFECT AND ITS EXPLANATION}

What was the experiment about? Knobe presented two stories to the respondents which differed in the side effect of the described action. In one situation, the respondents had to deal with "harming" and in the other with "helping". As per the questionnaire, the story, for the purpose of this article referred to as the "harming form", is as follows": The vice-president of a company went to the chairman of the board and said: "We are thinking of starting a new program. It will help us increase profits, but it will also harm the environment." The chairman of the board answered: "I don't care at all about harming the environment. I just want to make as much profit as I can. Let's start the new program." They started the new program. Sure enough, the environment was harmed ${ }^{9}$.

The first question asked by Knobe to the respondents was as follows: Did the director intentionally cause harm to the environment? The second was: Evaluate the level of the director's responsibility for harming the environment. The story according to the "helping form" was very similar: The vice-president of a company went to the chairman of the board and said: "We are thinking of starting a new program. It will help us increase profits, but it will also help the environment." The chairman of the board answered: "I don't care at all about helping the environment. I just want to make as much profit as I can. Let's start the new program." They started the new program. Sure enough, the environment was helped ${ }^{10}$.

In the results obtained, an asymmetry in the assessment of the intentionality of inducing a side effect was revealed. As many as $82 \%$ of those who received the "harming form" stated that the company director had intentionally caused harm to the environment. According to the standard understanding of intentional action ${ }^{11}$, such a result is incorrect

8 The translation of the story and questions is derived from: K. Kuś, B. Maćkiewicz, Z rozmysłem, ale nie specjalnie. O językowej wrażliwości filozofii eksperymentalnej, Filozofia Nauki 95(2016)3, 91-92.

9 J. Knobe, Intentional Action and Side Effects in Ordinary Language, op. cit., 191.

10 Ibid, 191.

11 In the philosophy of action, the so-called standard understanding of "intention- 
because the director had no such intention. On the other hand, 77\% of the respondents who received the "helping form" considered that the company director did not intentionally help the environment, which can be deemed a correct result ${ }^{12}$. It is also interesting to note that the answers concerning the attribution of intentionality are correlated with those concerning guilt and praise. This means that those who pointed out the director's guilt in the "harming form" also indicated his intention to cause a side effect. A similar situation occurs in the "helping form". Those who did not indicate the praiseworthiness of his act were at the same time unwilling to attribute intentionality to the side effect he produced. This led Knobe to formulate a thesis that the moral views of the respondents or their moral evaluation of the effects caused influence their judgement on the attribution of intentionality to the actions in question. Therefore, the asymmetry in the attribution of intentionality to actions is the result of their different moral evaluation ${ }^{13}$.

One of the solutions which, according to Agnieszka Dębska ${ }^{14}$, most widely explains the asymmetry in attributing intentionality to actions is

al action" (Simple View) is distinguished, as indicated, among others, by F. Adams, $\mathrm{H}$. McCann. An action is considered to be intentional if the subject of the action had the intention to cause a given effect. Not all actions can be explained by referring to the standard view. Other views associate the decision on the intentionality of action not so much with intention, but with the action anticipated by the subject and the acceptance of its consequences (G. Harman, M. Bratman, A. Mele). In such a situation, an action may also be intentional if the subject had no intention of doing it. See also, M. Piekarski, Dwa argumenty na rzecz tezy o predykcyjnym charakterze racji działania, Studia Philosophiae Christianae 54(2018)1, 93-119.

12 Knobe assumed that the result of the study could have been distorted due to the specific attitude of people towards large corporations. Therefore, he repeated the experiment, presenting a different story. It is irrelevant to our analyses, as the results of the research proved to be reproducible, cf. J. Knobe, Intentional Action and Side Effects in Ordinary Language, op. cit., 191.

13 J. Knobe, Intentional Action and Side Effects in Ordinary Language, op. cit. 190-194; Idem, Intentional Action in Folk Psychology. An Experimental Investigation, Philosophical Psychology 16(2003)2, 309-324; Idem, Intention, Intentional Action and Moral Considerations, Analysis 64(2004)2, 181-187.

14 A. Dębska, Wnioskowanie na temat intencjonalności działania w ujęciu filozofii eksperymentalnej, Filozofia Nauki 21(2013)3, 145. 
the theory of responsibility of J.C. Wrigth and J.Bengson ${ }^{15}$.Its main advantage is that it tries to provide a solution that will constitute a theory of asymmetric evaluation of responsibility in its broadest sense. As a result, it could explain not only the so-called Knobe effect, but also other cases of asymmetry. These include accidental actions (resulting from a lack of skill) or those resulting from fortune, e.g. uncontrolled pulling of the trigger resulting in hitting the center of the target or a person, as well as actions aimed at throwing a "six" on the dice. In such circumstances, the respondents define morally tinged actions as intentional actions ${ }^{16}$ and those that can be described as morally neutral as unintentiona ${ }^{17}$. Situations have also been observed in which the respondents tend to assess certain activities as intentional when their side effects are negative but morally neutra $1^{18}$. This refers to a case when, in order to increase a company's overall profit, a sales increase occurs in one of its branches while a decrease takes place in another ${ }^{19}$. The results of another experiment in which the participants of the study were presented with a story of a drunk driver who lost control of the vehicle and killed a family of five showed that the respondents blamed the perpetrator for causing the deaths of random people, but they did not attribute intentionality to his actions $^{20}$.

An important change, as Dębska notes, proposed within the framework of the theory of responsibility, compared to the classical

15 J. C. Wright, J. Bengson, Asymmetries in Judgments of Responsibility and Intentional Action, Mind and Language 24(2009)1, 24-50.

16 In Butler's and later Knobe's research, the moral value of the effect, in the context of which the intentionality of an action is attributed, is presented negatively - death of a person and harm to the environment, respectively.

$17 \mathrm{~J}$. Knobe, The Concept of Intentional Action. A Case Study in the Uses of Folk Psychology, op. cit., 203-231.

18 Knobe and Mendlow formulate an example referring to the decision of the managing directors of the corporation concerning the sales. The authors of the study assume that the change in the level of sales itself is morally neutral. The adoption of such a position, in the context of a broader ethical analysis, is not so obvious.

19 J. Knobe, G. Mendlow, The Good, the Bad, and the Blameworthy. Understanding the Role of Evaluative Reasoning in Folk Psychology, Journal of Theoretical and Philosophical Psychology 24(2004)2, 252-258.

20 T. Nadelhoffer, The Butler Problem Revisited, Analysis 64(2004)3, 277-284. 
theory of error, is the link between the concepts of responsibility and intentionality. The determination of whether an action was intentional does not depend on the attribution of guilt, but on the determination of responsibility ${ }^{21}$. Proposing a solution based on the theory of error, Malle and Nelson put forward a hypothesis that in cases of actions marked by negativity and guilt, the respondents tend to attribute intentionality to such actions. The authors suggest that this results from an emotional attitude emerging during the analysis of a given story, under the influence of which the respondents are inclined to look for information increasing the negative image of the subject assessed. Consequently, intentionality is linked with guilt. However, such an approach is contradicted by the research conducted by Thomas Nadelhoffer ${ }^{22}$, which showed that although the respondents blame the drunk driver for causing the accident, they do not attribute intentionality to his actions.

However, what is puzzling about both concepts is that both Malle and Nelson, as well as Wright and Bengson try to link the issue of intentionality with the notions of "guilt" or "responsibility" and not with the notion of "intention". On the one hand, the determination of the degree of correlation between the individual concepts allows to determine the direction of further research. On the other hand, it assumes a certain essential relationship between the concept of intentionality of action and other concepts. This approach to the problem from the very beginning treats the concept of intentionality of action as a derivative of other concepts or complex processes. Thus, it suggests a certain paradigm that does not allow the concept of intentionality to be treated in an autonomous manner. Therefore, it is worth looking at the issue of intentional action in a wider context.

21 B. F. Malle, S. E. Nelson, Judging Mens Rea. The Tension Between Folk Concepts and Legal Concepts of Intentionality, Behavioral Sciences and the Law 21(2003)5, 563-580.

22 T. Nadelhoffer, The Butler Problem Revisited, op. cit., 277-284. 


\section{MORALITY AND COGNITION}

The vast majority of published analyses concerning the "Knobe effect" are conducted from the perspective of the tradition of analytical philosophy. Therefore, all references to morality and ethics are naturally combined with different kinds of ethics of principles. In this article, an attempt will be made to broaden this perspective with the tradition of teleological ethics and, as a point of reference, we will use Thomistic ethics in its broadest sense.

Philosophical investigations from an ethical perspective should begin with the question of what morality is. The clarification of the understanding of morality is an important element of further analyses. It will provide a better understanding of Knobe's moral thesis and a new look at the importance of positive and negative side effects affecting the attribution of intentionality. However, it is not a matter of providing a comprehensive answer to the question of what morality is, but a matter of pointing out the problems associated with understanding morality. Note that when we use the term "moral", we indicate certain properties of an object. Not only deeds, but also judgments, norms, experiences, attitudes, or patterns are moral. There is also often talk of a moral mind or sense, as well as of a moral $\operatorname{man}^{23}$.

We should ask ourselves what the term "morality" refers to. When we talk about "morality", do we define the area of research interest, most often free and conscious human acts, and what is described as amoral will not be studied by ethics? Or rather, when using the term "morality", will we indicate the recommended attitudes within a specific ethic ${ }^{24}$ ? The questions posed are important given that they are largely omitted and overlooked in studies and analyses of the Knobe effect. The first way of understanding morality as a specific property or quality of a state of affairs, as mentioned above, is different from the second way of understanding morality as a certain evaluation. The term

23 J. Krokos, Sumienie jako poznanie. Fenomenologiczne dopełnienie Tomaszowej nauki o sumieniu, Wydawnictwo Naukowe UKSW, Warszawa 2004, 135.

24 The phrase "Christian morality" indicates attitudes that are to characterize Christians and constitute a pattern of behaviour for them. 
"morality" then appears as an expression of approval and stands in opposition to what is described as immoral. In other words, the distinction can be reduced to questions: "What is morality?", which is a question concerning the essence of morality and the criterion of morality, and to the question "What is moral?", that is "What should I do and why?", which is a question concerning the standard of morality and its source $^{25}$. In a different approach to this issue, although it does not seem to be entirely accurate, there is talk of morality defined descriptively and normatively ${ }^{26}$. In the Polish ethical tradition, a distinction is usually made between morality, which should be understood descriptively in this context, and ethics as a reflection on morality and on how one should $\mathrm{act}^{27}$. Taking into account the above-mentioned distinctions, ethics should be understood as morality defined normatively.

The awareness of the existence of both dimensions of morality enables a more detailed analysis not only of Knobe's moral thesis, but also of the structure of history in which the asymmetry in attributing intentionality to actions is revealed. It is necessary to consider whether the attribution of intentionality is influenced by the moral views of the respondents or their moral judgments, or by the very nature of the analysis of the problem presented. In other words, and assuming that Knobe's hypothesis is valid, whether this asymmetry results from treating the stories presented as a "moral problem" or as a "cognitive problem". It refers primarily to the cognitive methodology and normative competence that would be responsible for distinguishing between cognition "informing about facts" ("purely informative" cognition) and "moral" cognition, i.e. informing about the moral classification of perceived objects. It should be noted that every cognition informs about something, although it is necessary to distinguish between the two types or aspects of cognition

25 T. Biesaga, Spór o normę moralności, Wydawnictwo Naukowe Papieskiej Akademii Teologicznej, Kraków 1998, 9.

26 B. Gert, J. Gert, The Definition of Morality, in: The Stanford Encyclopedia of Philosophy, ed. E. N. Zalta, (Spring 2016 Edition), (https://plato.stanford.edu/archives/ spr2016/entries/morality-definition/), [accessed on: 12/2017].

27 M. Ossowska, Podstawy nauki o moralności, Państwowe Wydawnictwo Naukowe, Warszawa 1963, 9-23. 
mentioned above: "informing about facts" and "informing about moral judgments". It is primarily a matter of perceiving a certain metalevel, concerning the perception of reality from a moral perspective. In other words, it can be assumed that cognition "informing about facts" means cognition that informs about the objective state of affairs or refers to cognitive processes and the structure of cognition itself. It is most often expressed in descriptive sentences and statements ${ }^{28}$. On the other hand, cognition "informing about moral judgements" means value cognition, indicating a certain non-empirical property (quality) of the recognized object (good/bad; valuable/non-valuable; morally ordered/forbidden) or relating the data of cognition to norms or moral values recognized by the subject of cognition. It is most often expressed in value sentences and evaluating statements ("This is a good man"; "His actions were bad") 29.

\section{SCOPE OF MORALITY}

One more question should be asked. If the attribution of intentionality to actions is influenced by moral factors, than is the classification of the act or problem as moral done because it is an act that meets certain conditions or because it is related to something, such as a norm or a value? Another fundamental question will refer to what allows us to conclude that a given story is morally tinged. This question is important above all from the perspective of the interpretation of the whole phenomenon discussed. Knobe and Mendlow constructed another research form that contained a story concerning sales exclusively. In the story, the natural (main) effect was an increase in sales in one branch of the company and, as a side effect, there was a slight decrease in sales in another branch ${ }^{30}$. In Dębska's interpretation ${ }^{31}$, the reconstructed story would be morally

28 However, it should be remembered that descriptive statements can also be morally tinged.

29 The distinction between evaluating and descriptive statements is also applied by Z. Ziembiński, Analiza pojęcia czynu, Wiedza Powszechna, Warszawa 1972, 15-17.

30 J. Knobe, G. Mendlow, The Good, the Bad, and the Blameworthy, op. cit., 252-258.

31 A. Dębska, Wnioskowanie na temat intencjonalności działania w ujęciu filozofii eksperymentalnej, op. cit., 146-148. 
neutral, although neither Knobe nor Mendlow explicitly indicate this. The results of the survey constitute the main argument in favour of a morally neutral perception of the constructed story. The respondents were unwilling to attribute guilt, even though they considered the act of the perpetrator as intentional. This could mean that regardless of the type of effects caused, they are perceived as morally neutral. However, in reality it does not have to be so. The application of the criterion of guilt and praise does not have to determine the morality or immorality of a given action or effect ${ }^{32}$. According to the Thomists, the answer to the question concerning the scope of morality will, in most cases, lead to the conclusion that there are no morally indifferent (neutral) acts ${ }^{33}$. However, from the perspective of ethics based on principles, the preferred attitude is that there are morally neutral actions, i.e. actions that go beyond the moral classification. What would such an attitude lead to? Knobe claims that the moral valuation of side effects affects the attribution of intentionality to actions ${ }^{34}$. However, he does not address the valuation of the main effect, which under these circumstances is either not morally valued or its moral valuation does not affect the attribution of intentionality. From the perspective of Thomistic ethicists, both effects are morally tinged because they are the result of actions and can or should affect the attribution of intentionality. Such an approach would lead to the assumption of the Wide Moral Valence Hypothesi ${ }^{35}$, under which the relationship between the moral valuation of the main effect and the moral valuation of the side effect significantly influences the attribution of intentionality to actions. The aforementioned distinction between actions that are intentional and events that are impulsive,

32 In this use of the term, morality is a dimension that describes (classifies) a given act or effect rather than evaluating it as good or bad.

33 In Poland, for years, there has been a discussion among ethicists about the concept of morality and, consequently, about the very scope of morality. Works by authors such as K. Frankel, J. Woroniecki, J. Keller, T. Kotarbiński, I. Lazari-Pawłowska, M. Ossowska, T. Ślipko, H. Juros, T. Styczeń, A. Szostek, B. Chyrowicz should be mentioned.

$34 \mathrm{~J}$. Knobe, The Concept of Intentional Action. A Case Study in the Uses of Folk Psychology, op. cit., 212-228.

35 Articles referring to empirical research and developing the hypothesis of broad moral valuation are being prepared. 
unconditional or understood from a purely cause-and-effect point of view must be taken into account ${ }^{36}$. In the terminology of some Thomists, these would be unconscious (irrational) acts, which originate from other human powers, without the participation of their reason and will ${ }^{37}$. When analyzing the differences between "action" and "event", Friedo Ricken stresses that the difference lies in justification. In the case of an "event", the answer to the question "why?" will be a preceding event, meaning that the focus should be on the cause-and-effect relationship. In the case of an "action", the answer to the question "why?" will be intention. Sometimes, in such a situation, there is talk of an "intentional" causation. Therefore, what distinguishes actions from events are intentions ${ }^{38}$. This may be important for understanding the emerging asymmetry in attributing intentionality to actions.

When asking what morally neutral (amoral) acts are, one should also answer the question about the scope and type of morality. Let us keep in mind that, in the context of the Thomistic tradition, we are working within the area of norms which determine the scope of morality and moral obligations. Let us add that the broad issue of values, which depends to a large extent on the way they exist, characteristic of phenomenological ethics, is pushed aside at this point. Therefore, when addressing the concept of morality, let us note that one can distinguish its two main understandings, two types of morality ${ }^{39}$. The first understanding is focused on the personal dimension of man and is referred to as individual or autonomous morality. Within this type of morality, moral evaluation is carried out from a personal perspective, and the application of moral norms has its origin in their recognition (in conscience) and not in the external body that adopts them. This approach to morality is essentially in line with the Thomistic tradition ${ }^{40}$. The second understanding of morality emphasize the existence of norms that define social morality.

36 F. Ricken, Etyka ogólna, transl. P. Domański, Wydawnictwo ANTYK, Kęty 2001, 73-74.

37 T. Ślipko, Zarys etyki ogólnej, Wydawnictwo WAM, Kraków 2004, 75.

38 F. Ricken, Etyka ogólna, op. cit., 73.

39 N. Cooper, Two Concepts of Morality, Philosophy 155(1966), 19-33.

40 Z. Sareło, Sumienie - zobowiązujący dar, in: Meandry etyki, ed. Z. Sareło, Wydawnictwo Wszechnicy Mazurskiej. Acta Universitatis Masuriensis, Olecko 2001, 113-130. 
The sense of duty plays an important role in it, and it is often combined with statutory law. Morality understood in this way is often referred to as positive morality. However, it must be borne in mind that it cannot be equated with the law. This understanding of morality functions very strongly in the tradition of analytical philosophy or, more broadly, Anglo-Saxon philosophy, largely due to liberal philosophers of politics and law who promote the idea of contract.

The strong influence of the understanding of morality as social morality can be seen i.a. in the argumentation of Katarzyna Paprzycka. It refers to the existence of a social obligation to help the environment. Such an attitude would assume the acceptance of the existence of such an obligation by all respondents, which would justify blaming the president of the company for their failure to meet this obligation. As a result, the respondents could attribute intentionality to an action that would harm the environment ${ }^{41}$. The way of explaining the Knobe effect proposed by Paprzycka assumes a specific vision of morality and the development of a certain argumentation that would not be possible under the conditions of individual morality. This very clearly shows how important the adopted concept of morality is for confirming Knobe's moral thesis. Of course, the presented distinction between individual and social morality does not exhaust the problem of understanding morality, but it does indicate the possibility of more fundamental problems that may arise if this distinction is overlooked ${ }^{42}$. It mainly concerns the scope of morality. In the case of social morality, the scope of norms is more limited. First of all, for the most part, it does not apply to the norms relating to the so-called "private sphere", that is, the area that includes, among other things, a commitment to oneself ${ }^{43}$; secondly, cer-

41 K. Paprzycka, Rozwiq̨zanie problemu Butlera i wyjaśnienie efektu Knobe’a, Filozofia Nauki 22(2014)2, 73-96; Idem, O intencjonalności działań i zaniechań, czyli o społecznej naturze sprawstwa, Przegląd Filozoficzny - Nowa Seria 97(2016)1, 45-65.

42 J. Grzybowski, A. Jaworska, A. Kazimierczak-Kucharska, A. Norwa, A., Waleszczyński, S. L. Zalewska, Sposób na filozofię. Kluczowe zagadnienia z dydaktyki przedmiotowej, Liberi Libri, Warszawa 2016, 72-74.

43 R. Moń, Obowiq̨zki moralne wobec siebie. O różnicy między wolnościa polityczna a moralna, in: Primum philosophari. Opuscula Antonio Siemnianowski dedicata, ed. D. Olejniczak, WT UAM, Poznań 2016, 317-332, T. Buksiński, Moralność warunkowa 
tain areas of human life may be excluded from the norms of social morality, such as specific practices of family life.

Let us return to morally neutral actions. There is no consensus among ethics on morally neutral (indifferent) acts. In the Thomistic tradition, there is generally a consensus that an act that is indifferent to its object (e.g. walking, eating) ceases to be indifferent in a particular situation ${ }^{44}$. This is mainly due to the purposefulness of the act. Utilitarian ethics also belong to the tradition of ethics of principles. Within them, one is dealing with the "measurement" of the overall level of happiness, thus a specific action can be morally neutral. This occurs when an act contributes neither to the increase nor decrease in overall happiness. However, this is done with reference to the guiding principle. Therefore, both in the utilitarianism of rules and motives, we deal with a moral indifference to actions ${ }^{45}$. The situation will be presented differently in the views of Richard B. Brandt, who draws attention i.a. to "reprehensible" and "morally praiseworthy" acts ${ }^{46}$. In his definition, in terms of our analyses ${ }^{47}$, it is important that one sees that, due to the nature of the acting subject, among the less and more desirable acts, there are certain acts that may be average or affect the mediocrity of the (moral) nature of the subject performing them. This means that within the framework of moral analysis, one can distinguish the existence of a certain group of acts which, depending on the ethical tradition, will not be subject to moral evaluation or will be morally neutral (indifferent).

Concluding the topic concerning the determination of the area of morality and the scope of potential analyses made from a moral perspective, it is worthwhile to note the moral categories that are used in

i bezwarunkowa, in: Ibid, 259-268.

44 T. Ślipko, Zarys etyki ogólnej, op. cit., 188.

45 N. Szutta, Utylitaryzm wobec krytyki etyków cnót, Diametros 11(2007)1, 54-55.

46 R. B. Brandt, Etyka. Zagadnienia etyki normatywnej i metaetyki, transl. B. Stanosz, Wydawnictwo Naukowe PWN, Warszawa 1996, 778-780.

47 " $X$ is morally good" means nothing more than: " $Y$ did $X$, and $X$ would not have occurred had not the character of $Y$ been in some respect less desirable than average". R. B. Brandt, Etyka. Zagadnienia etyki normatywnej i metaetyki, op. cit., 780. The author provides an explanation and develops the presented definition, being convinced that no simple definition seems satisfactory. There is no room for developing this topic in this article. 
the analysis of the Knobe effect. In his initial experiment, besides the question of intentionality, Knobe himself posed the question concerning guilt and the reason for causing a side effect. The category of guilt was also used by Malle and Nelson, combining it with the tendency for the respondents to create a negative image of an actor when the effect $s$ of their actions were morally negative. This problem was approached a bit differently by C. Wrigth and J. Bengson, using the category of responsibility, with a special distinction between negative and positive responsibility. Although they separate the category of guilt and merit from the category of positive and negative responsibility, the moral categories they distinguish seem to be identical. When analyzing the results of the research from the perspective of responsibility, one should also remember to distinguish legal responsibility from moral responsibility, as well as to distinguish those two types of responsibility from responsibility as such, i.e. the very phenomenon of responsibility, described by J. Filek as a non-adjectival responsibility functioning on a metaphysical or ontological level ${ }^{48}$. However, this is merely a partial use of the potential of the ethical perspective. In personalistic concepts, a category of a good deed dependent on the intentions of the perpetrator and a righteous deed conditioned by the objective state of affairs will appear. Phenomenologists will add a category of value, or more precisely the realization of value or anti-value, depending on whether the subject responds to it. In the tradition of Thomistic ethics, the issue of valuation will also arise, but the category of ultimate goal will be much more important. Given the abundance of possible ethical analyses depending on various traditions, Knobe's moral hypothesis should be reviewed in a new light.

\section{MORAL RESPONSIBILITY FROM A THOMISTIC PERSPECTIVE}

The problem presented in Knobe's stories refers to classical ethical and legal discussions about responsibility. They describe a situation in which one decision (action) has two effects. In classical dilemmas referring to the principles of double effect, already formulated by

48 J. Filek, Filozofia odpowiedzialności XX wieku, Wydawnictwo ZNAK, Kraków 2003, 9-10. 
St. Thomas the main effect is intended and good (positive), while the side effect is not intended and is assessed as bad (negative). A significant modification conducted by Knobe is that in one story, the side effect produces positive results. It is worth emphasizing that the principles of double effect formulated by St. Thomas concerned the problem of attributing responsibility for a given act and whether the perpetrator of such an act should be to blame for it (in a moral sense). However, in the context of the Knobe effect, there is something else that requires attention. The story itself, its narrative, does not directly raise either the problem of guilt or the problem of responsibility. It is only the questions asked in both stories that reveal the individual problem layers. Therefore, the "moral undertone" can have a much broader dimension, not only in terms of moral responsibility and guilt.

In the interpretation of the discussed research results, it is important to understand the side effect. Knobe had to clarify this term due to the emerging doubts. He understands the side effect to be a certain result that the perpetrator did not specifically try to achieve, but predicted that it would appear as a result of the action taken ${ }^{49}$. In the Thomistic tradition, this would require further clarification. It should be remembered that Thomistic ethics is teleological ethics and the reference to the purpose of action plays an important role in moral evaluation. This is a fundamentally different approach to considering moral issues than that found in principle-based ethics. Therefore, first of all, when speaking of intention, one should still distinguish between directly intentional acts (an intentional act in itself), which is the positive fulfillment of an action, and indirectly intentional acts (an act intentional in its cause), which means the discontinuation of an action ${ }^{50}$. Katarzyna Paprzycka tries to explain the occurrence of the Knobe effect precisely by means of the category of a discontinued action, which refers to the fulfilment of the social obligation to care for the environment, attributed by the respondents ${ }^{51}$. Secondly, it is also important to specify the issue of the

49 J. Knobe, The Concept of Intentional Action. A Case Study in the Uses of Folk Psychology, op. cit., 206-207.

50 T. Ślipko, Zarys etyki ogólnej, op. cit., 421.

51 K. Paprzycka, Rozwiq̨zanie problemu Butlera i wyjaśnienie efektu Knobe’a, op. cit., 73- 
causal relationship between the resulting effects and the actor and their decision. Without going into detail, one should be aware of the following relationships. A situation of co-occurrence of a different cause may occur and, as a result of these specific two or more causes, which may occur simultaneously or in succession, a specific side effect appears. There may also be a situation in which one and the same action simultaneously produces two effects, but its sole (necessary) cause is the actor $^{52}$. This distinction is omitted in analyses of the moral impact on the assessment of intentionality. Therefore, the example of a sniper who, by taking a shot - as a side effect - informs about his position, is fundamentally different from the example contained in Knobe's stories ${ }^{53}$. However, analysis of the issue of intentional action in the context of the above remarks would require separate investigations.

To sum up the topic undertaken, according to Tadeusz Ślipko, a Thomist, a directly intentional act is defined as any conscious act in which a person intends a certain action (effect) regardless of any ad hoc combination of external factors, even though it (he) appears in the structure of an action merely as a side effect ${ }^{54}$. The structure of the action, that is the shooting, entails the generation of a bang, which at the same time indicates the source of its origin. Therefore, in the example with a sniper, informing about one's position as a result of a shot will be considered by a Thomist ethicist as a directly intentional act, even though it occurs as a side effect. An indirectly intentional act, on the other hand, is a conscious act in which a person knows that a certain action and its natural effect, which they directly intend to produce, is associated, through the interaction of an external cause, with yet another side effect, no longer intended by them, but only permitted and tolerated because of sufficiently important reasons ${ }^{55}$.

96; Idem, O intencjonalności działań i zaniechań, czyli o społecznej naturze sprawstwa, op. cit., 45-65.

52 T. Ślipko, Zarys etyki ogólnej, op. cit., 424.

53 G. Harman, Practical Reasoning, Review of Metaphysics 29(1976)3, 433.

54 T. Ślipko, Zarys etyki ogólnej, op. cit., 427.

55 Ibid. 
Knobe's stories relate precisely to indirectly intentional acts, i.e. actions that take into account the occurrence of side effects, but are permitted or tolerated by the actor for reasons important to them. From a Thomistic perspective, even though the president of the company says: "I don't care ... . I just want ...", it does not mean that he does not address the side effect intentionally. Friedo Ricken will even speak about "intentional" causation. This is where a space for the analysis of the "moral undertone" of the evaluations or the attribution of intentionality appears. Moral factors may relate to the weighing of moral reasons for agreeing to a side effect. However, this requires the definition of at least two things. First of all, what can be considered a moral rationale, secondly, what will be "weighed" and whether the "weighing" will only take into account the empirical, quantifiable consequences, or certain non-empirical properties, qualities of individual objects or arguments as well. The presented approach allows one to extend the space for the analysis of moral factors that can influence the assessment of the intentionality of an action to such issues as goodness, value or moral rationale. It may also be the case that the concept of intentionality can be applied differently depending on whether a given problem is considered as an ethical issue or as an epistemological issue. This would consequently lead to the formulation of a thesis about the existence of two types of intentionality: cognitive and ethical. Testing such a thesis would require detailed empirical research. In this article, we aim to check whether there would be a theoretical basis for this.

\section{THE PROBLEM OF NORMATIVE ORDERS AND COMPETENCES}

In the article entitled Person as scientist, person as moralist ${ }^{56}$, Knobe proposed to test the "person-as-scientist theory", which could provide the right approach to understanding certain aspects of our daily cognition ${ }^{57}$. He presented it in the form of a metaphor. He suggested that the common way of creating the sense of the perceived world functions on the

56 J. Knobe, Person as scientist, person as moralist, op. cit., 315-329.

57 Ibid, 317. 
principle of a modern university with its division into individual faculties and institutes. This approach would suggest that there are separate processes responsible for constructing a "scientific" perception of the world around us. Translating this into a problem of competence, Knobe tried to test the hypothesis that some basic competences are "scientific" by their nature, but there may exist certain factors, e.g. in the form of moral considerations, that prevent the correct application of these competences. However, he did not rule out the possibility that there is no basic level of competence in which cognitive abilities can be considered "scientific". Therefore, cognitive processes could prove to be sufficiently developed through moral considerations ${ }^{58}$. However, he ultimately concluded that research on human cognition does not indicate that such a rigid division exists, although one can distinguish between processes relating to moral issues and others often considered "scientific". He also put forward a stronger thesis that processes that indeed appear as "scientific" actually take into account moral reasons. This led him to the conclusion that we are thoroughly moral beings ${ }^{59}$.

In agreeing with Knobe's final conclusions about the moral nature of man and the strong influence of moral judgments on decisions of a "scientific" nature, we cannot agree with him that it is impossible to distinguish between these two normative orders in common reasoning. One should start with the very understanding of competence. I assume that for a Thomist, competence will be associated with the classical understanding of virtue as the ability to do something rather than with processes seen as psychological, consisting in choosing some alternatives and ignoring others ${ }^{60}$. The difference in the two approaches would be that in the psychological approach, we focus on the criterion of choosing a given alternative, while from a philosophical perspective, in addition to recognizing the given alternative within the adopted criterion, there must be a conscious choice (will). The mere fact of indicating the existence of a certain tendency, and in our case it will be the existence

58 Ibid.

59 Ibid, 328.

60 Ibid, 326. 
of a tendency to asymmetrically attribute intentionality to actions depending on positive or negative effects, does not prove that it is correct or incorrect, nor does it indicate whether the "scientific" choice is influenced by moral factors. The mere observation of the difference between the side effect in the "harming form" and the side effect in the "helping form" is made in moral categories and refers to the real difference between the effects (helping, harming) and not a logical difference ( $p, \neg p)$.

Therefore, it should be decided that on one occasion we are dealing with a "scientific" approach, and in other situations with a moral approach, and not a morally tinged "scientific" approach. The moral context of the situation may influence the respondents in such a way that they will apply the criteria of moral rather than "scientific" evaluation. An important factor may be the relationship between the moral weight of the side effect and the moral weight of the main objective of the action. This relationship is especially taken into account in the Thomistic case studies referring to the doctrine of double effect. However, the choice to judge a given situation in a "scientific" or moral manner would be determined by the normative competence of the respondent allowing them to distinguish between the moral and non-moral order.

In the above-mentioned context, the cognitive competences responsible for cognition "informing about facts" and moral competences are different from normative competences, understood as the ability to identify and distinguish data obtained in cognition and mediated in language. We will use an example. The death of an animal, as an observed event, can be identified as follows: (1) taking the life of a living creature; (2) killing an animal; (3) hunting an animal; (4) obtaining food. From the perspective of Thomistic ethics, the subject cognizing an action in order to morally classify a given act must attribute to it a certain purposefulness or intention, even if the act or event is considered in itself ${ }^{61}$. In such situations, the influence and role of moral judgments becomes apparent. Therefore, the ability to refrain from attributing this purposefulness (intention) despite the existence of a certain tendency

61 At this point, I omit the important question raised among Thomistic ethicists as to whether there are any acts that are good or bad in themselves. 
may depend precisely on the normative competences that would be responsible for separating and identifying individual data. In other words, the cessation of an animal's vital signs is a biological fact, and as such, it has no moral value or judgement. Only when expressed in language can it take on a moral character, as it will be the death of someone's guardian or the murder of an innocent being.

The approach presented could be introduced by the example of a coin, the reverse and obverse of which would be the cognition "informing about facts" and cognition "informing about moral evaluation", respectively, which are determined by the corresponding normative orders. The right competences would be correlated with these two orders. The edge of the coin, on the other hand, would represent the normative competences that would be responsible for the ability to consciously move from one order to another. The legitimate question is whether such a radical separation, using Knobe's terminology, of "scientific" order and moral order is justified. An affirmative answer can be given if the existence of morally neutral acts is rejected. As has already been presented, this perspective is close at least to the ethics of the Thomistic and phenomenological tradition. In this context, the answer to the question of what morality is will play a key role. Depending on this answer, the moral thesis used to explain the Knobe effect may take on a completely different meaning.

It is worth noting that within the framework of the investigations focused on the issue of normativity, but carried out from an epistemological perspective, the research insights presented seem to be approved by Michał Piekarski, who claims that normativity is co-present in every possible personal experience understood in the sense of phenomenological clarity ${ }^{62}$. This allows him to distinguish between the normative and the empirical. It also enables him to formulate the thesis about the existence of orders that are primarily normative and orders that are secondarily normative ${ }^{63}$. These findings are an attempt

62 M. Piekarski, Od typiki doświadczenia do normatywnej antycypacji. Przyczynek do fenomenologii normatywności, op. cit., 85.

63 Idem, Efekt Knobe’a, normatywność i racje działania, op. cit., 123. 
to break out of a certain paradigm that associates the issue of normativity exclusively with law and morality. The combination of both research perspectives, epistemological and moral, could result in the formulation of a general normativity theory.

\section{CONCLUSIONS}

The investigations presented, carried out in the context of the Thomistic tradition, were intended to show in a broader light how the practice of ethics and approaches to understanding morality can influence the setting of research directions in the dynamically developing experimental philosophy. The analyses conducted have shown that adopting a perspective that rejects the existence of morally neutral acts may change the interpretation of the causes of asymmetry revealed in the experiments in question. In addition, a new possibility of explaining the Knobe effect was indicated. It is based on the assumption that human cognition has a double nature. On the one hand, it informs us about the facts; on the other hand, it provides information about the moral evaluation of the objects being cognized. Therefore, in the stories analyzed by the respondents, it is not so much the influence of moral factors on "scientific" cognition that may be revealed as the mixing of cognitive and normative orders. The research carried out within the framework of experimental philosophy may capture certain tendencies and prompt researchers to seek clarification of these phenomena. They may also try to answer the question as to whether the resulting asymmetry is caused by underdeveloped normative competences, which incorrectly identify and separate two normative orders: cognitive and moral. However, this requires further theoretical and empirical research.

\section{BIBLIOGRAPHY}

Biesaga T., Spór o normę moralności, Wydawnictwo Naukowe Papieskiej Akademii Teologicznej, Kraków 1998.

Brandt R. B., Etyka. Zagadnienia etyki normatywnej i metaetyki, transl. B. Stanosz, Wydawnictwo Naukowe PWN, Warszawa 1996. 
Buksiński T., Moralność warunkowa i bezwarunkowa, in: Primum philosophari. Opuscula Antonio Siemnianorwski dedicata, ed. D. Olejniczak, WT UAM, Poznań 2016, 259-268.

Cooper N., Two Concepts of Morality, Philosophy 155(1966), 19-33.

Dębska A., Wnioskowanie na temat intencjonalności dziatania w ujęciu filozofii eksperymentalnej, Filozofia Nauki 21(2013)3, 143-155.

Filek J., Filozofia odpowiedzialności XX wieku, Wydawnictwo ZNAK, Kraków 2003.

Gert B., Gert, J., The Definition of Morality, in: The Stanford Encyclopedia of Philosophy, red. E.N. Zalta, (Spring 2016 Edition), (https://plato.stanford.edu/archives/spr2016/entries/morality-definition/).

GrzybowskiJ.,Jaworska A., Kazimierczak-Kucharska A.,Norwa A.,Waleszczyński A., Zalewska S. L., Sposób na flozofię. Kluczowe zagadnienia z dydaktyki przedmiotowej, Liberi Libri, Warszawa 2016.

Harman G., Practical Reasoning, Review of Metaphysics 29(1976)3, 431-463.

Hindriks F., Douven I., Singmann H., A New Angle on the Knobe Effect: Intentionality Correlates with Blame, not with Praise, Mind and Language 31(2016)2, 204-220.

Knobe J., Intention, Intentional Action and Moral Considerations, Analysis 64(2004)2, 181-187.

Knobe J., Intentional Action and Side Effects in Ordinary Language, Analysis 63(2003)3, 190-194.

Knobe J., Intentional Action in Folk Psychology. An Experimental Investigation, Philosophical Psychology 16(2003)2, 309-324.

Knobe J., Mendlow G., The Good, the Bad, and the Blameworthy. Understanding the Role of Evaluative Reasoning in Folk Psychology, Journal of Theoretical and Philosophical Psychology 24(2004)2, 252-258.

Knobe J., Person as scientist, person as moralist, Behavioral and Brain Sciences 33(2010), 315-329.

Knobe J., The Concept of Intentional Action. A Case Study in the Uses of Folk Psychology, Philosophical Studies 130(2006)2, 203-231.

Krokos J., Sumienie jako poznanie. Fenomenologiczne dopetnienie Tomaszowej nauki o sumieniu, Wydawnictwo Naukowe UKSW, Warszawa 2004.

Kuś K., Maćkiewicz B., Z rozmystem, ale nie specjalnie. O językowej wrażliwości flozofii eksperymentalnej, Filozofia Nauki 95(2016)3, 73-101. 
Malle B. F., Nelson S. E., Judging Mens Rea. The Tension Between Folk Concepts and Legal Concepts of Intentionality, Behavioral Sciences and the Law 21(2003)5, 563-580. Moń R., Obowiązki moralne wobec siebie. O różnicy między wolnościa polityczna a moralna, in: Primum philosophari. Opuscula Antonio Siemnianorwski dedicata, ed. D. Olejniczak, WT UAM, Poznań 2016, 317-332.

Nadelhoffer T., The Butler Problem Revisited, Analysis 64(2004)3, 277-284.

Ossowska M., Podstawy nauki o moralności, Państwowe Wydawnictwo Naukowe, Warszawa 1963.

Paprzycka K., Analityczna filozofia dziatania. Problemy i stanowiska, in: Przewodnik po filozofi umystu, eds. M. Miłkowski, R. Poczobut, WAM, Kraków 2012, 465-494.

Paprzycka K., O intencjonalności dziatań $i$ zaniechań, czyli o spotecznej naturze sprawstwa, Przegląd Filozoficzny - Nowa Seria 97(2016)1, 45-65.

Paprzycka K., Rozwiqzanie problemu Butlera i wyjaśnienie efektu Knobe’a, Filozofia Nauki 22(2014)2, 73-96.

Piekarski M., Dwa argumenty na rzecz tezy o predykcyjnym charakterze racji dziatania, Studia Philosophiae Christianae 54(2018)1, 93-119.

Piekarski M., Efekt Knobe’a, normatywnośc i racje dziatania, Filozofia Nauki 97(2017)1, 109-128.

Piekarski M., Od typiki doświadczenia do normatywnej antycypacji. Przyczynek do fenomenologii normatywności, Filo-Sofija 33(2016)2, 71-86.

Ricken F., Etyka ogólna, tłum. P. Domański, Wydawnictwo ANTYK, Kęty 2001.

Sareło Z., Sumienie - zobowiqzujacy dar, in: Meandry etyki, ed. Z. Sareło, Wydawnictwo Wszechnicy Mazurskiej. Acta Universitatis Masuriensis, Olecko 2001, 113-130.

Szutta N., Utylitaryzm wobec krytyki etykórw cnót, Diametros 11(2007)1, 40-60.

Ślipko T., Zarys etyki ogólnej, Wydawnictwo WAM, Kraków 2004.

Wright J. C., Bengson J., Asymmetries in Judgments of Responsibility and Intentional Action, Mind and Language 24(2009)1, 24-50.

Ziembiński Z., Analiza pojęcia czynu, Wiedza Powszechna, Warszawa 1972.

Andrzej Waleszczyński

Cardinal Stefan Wyszyński University in Warsaw, Institute of Philosophy, Poland

ORCID: https://orcid.org/0000-0003-0426-3919

a.waleszczynski@uksw.edu.pl

DOI: 10.21697/spch.2020.56.S2.09 